Road Safety Effects of roundabouts in Flanders

Bram De Brabander, Erik Nuyts, Lode Vereeck

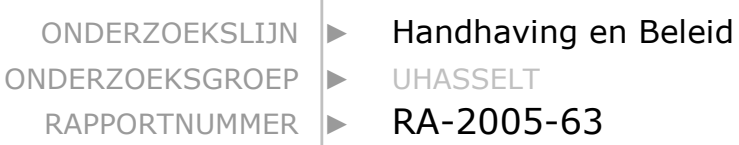

r RA-2005-63 



\section{Road safety effects of roundabouts in Flanders}

RA-2005-63

Bram De Brabander, Erik Nuyts, Lode Vereeck

Onderzoekslijn Handhaving en Beleid

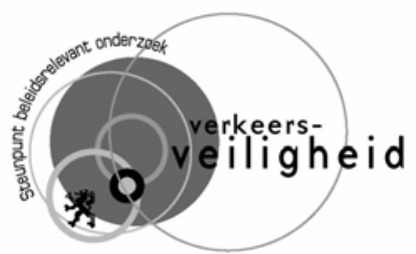

DIEPENBEEK, 2005.

STEUNPUNT VERKEERSVEILIGHEID. 


\section{Documentbeschrijving}

Rapportnummer:

Titel:

Ondertitel:

Auteur(s):

Promotor:

Onderzoekslijn:

Partner:

Aantal pagina's:

Trefwoorden:

Projectnummer Steunpunt:

Projectinhoud:
RA-2005-63

Road safety effects of roundabouts in Flanders

Bram De Brabander, Erik Nuyts, Lode Vereeck

Lode Vereeck

Handhaving en Beleid

Universiteit Hasselt

25

veiligheidseffecten, effectiviteit, rotonde, voor-na studie, lengte na-periode

5.1

Voor-na studie van 95 rotondes in Vlaanderen

Uitgave: Steunpunt Verkeersveiligheid, september 2005.

Op basis van deze paper werd ook een artikel gepubliceerd in J ournal of Safety Research, vol. 36 (3), p.289-296 (beschikbaar via www.elsevier.com). 


\section{Samenvatting}

In dit rapport wordt het effect op de verkeersveiligheid van 95 rotondes, gebouwd tussen 1994 en 1999, in Vlaanderen geanalyseerd. De resultaten geven aan dat het effect op het aantal en de ernst van de letselongevallen belangrijk is, maar ook verschillend is in functie van de snelheidslimiet op de wegen die uitkomen op de rotonde. Rotondes zijn het meest effectief wanneer ze liggen op wegen met een hoge snelheidslimiet $(90 \mathrm{~km} / \mathrm{u})$ met een aansluitende weg met een lagere snelheidslimiet (50 of $70 \mathrm{~km} / \mathrm{u}$ ).

De empirische resultaten laten een gemiddelde daling van $34 \%$ in het aantal letselongevallen zien (variërend tussen 15 en 59\%). Het aantal letselongevallen met enkel lichtgewonden daalt met $30 \%(14-45 \%)$ en letselongevallen met minstens één zwaargewonde dalen er met 38\% (27-72\%). In dit rapport wordt ook het effect op de resultaten nagegaan wanneer verschillende na-periodes (1, 3 of 6 jaar) in beschouwing worden genomen. Indien slechts één jaar na de plaatsing van de rotonde wordt opgenomen in de analyse is er voor alle locaties een belangrijke onderschatting van het effect op langere termijn. Indien alle resultaten worden geaggregeerd, is het effect op de verkeersveiligheid na 3 jaar vergelijkbaar met een periode van 6 jaar. Een effectief verkeersveiligheidsbeleid vraagt dan ook enig geduld van de beslissingnemers en is gebaat bij een voldoende lange na-periode voor een degelijke analyse. 



\section{Summary}

This paper analyzes the effect on road safety of 95 roundabouts that were built in Flanders between 1994 and 1999. The study shows that the effect on the number and severity of road accidents adjusted for the trend and regression to the mean is significant, but varies considerably in accordance with the speed limit regime on the intersection. Roundabouts are most effective on intersections of a main road with a high speed limit $(90 \mathrm{~km} / \mathrm{h})$ and a adjacent road with a lower speed limit (50 or $70 \mathrm{~km} / \mathrm{h}$ ). The empirical analysis reveals a reduction of 34\% (varying between 15 and $59 \%$ ) for the total number of injury accidents, 30\% (14-45\%) for light injury accidents and 38\% (27$72 \%$ ) for serious injury accidents. This study also takes a closer look at the impact of different post-implementation periods using accident data of one, three or six years after the construction of a roundabout on the calculated effectiveness results and warns for a severe underestimation when a one-year period is used. An effective traffic safety policy based on scientific results thus requires some patience from the policy-makers. 


\section{Table of contents}

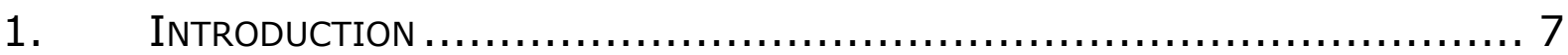

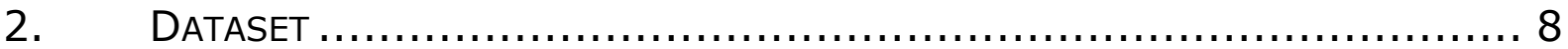

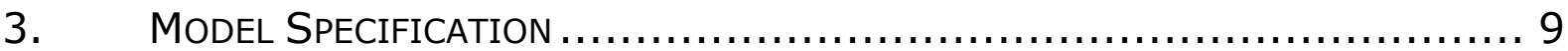

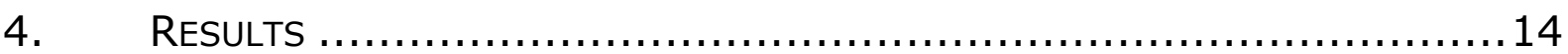

$\begin{array}{lll}4.1 & \text { Effectiveness of roundabouts } & 14\end{array}$

4.2 Time-series analysis of effectiveness 15

$\begin{array}{lll}4.3 & \text { Learning effects of road users } & 17\end{array}$

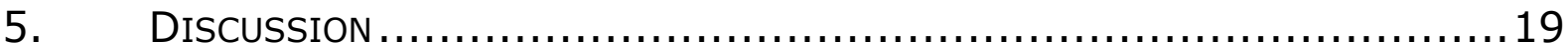

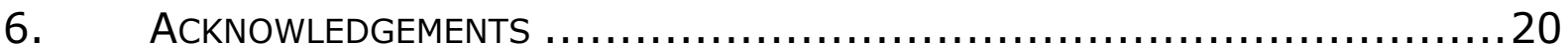

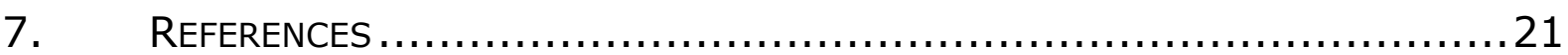

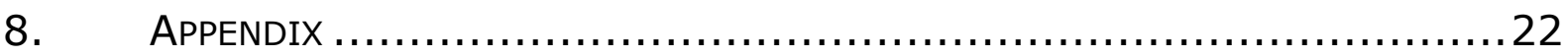




\section{I NTRODUCTION}

Effectiveness studies are helpful for designing and improving road safety policy. No such in-depth studies have ever been carried out for Belgium which has some of the worst traffic safety records in Europe ${ }^{1}$. Policy measures are allegedly taken by rules of thumb. When figures indicated for example that twice as many accidents occurred at crossroads than on other road segments in Flanders, (highways excluded) and that the accidents at the former locations gave rise to 1.5 casualties per accident compared to 1.3 on the latter, the Flemish government decided in 1993 to invest heavily in the construction of roundabouts. Arguably, roundabouts were and are reported to have various positive effects. Compared to signalised junctions, Hydén and Várhalyi (2000) observe a reduction of time consumption by 11 seconds per vehicle, noise level by $4 \mathrm{~dB}$, accidents by $46 \%$, yet a small increase of $\mathrm{CO}_{2}$ and $\mathrm{NO}_{x}$ emissions by $4 \%$ and $6 \%$. In their report, Robinson et al. (2000) found varying reductions in the number of injury accidents in Australia (between 45 and 87\%), France (between 57 and 78\%), United Kingdom (between 25 and 39\%) and the United States (51\%). Ogden (1996) demonstrated that the construction of roundabouts may reduce accidents by $60 \%$ to $80 \%$ at high speed intersections and $50 \%$ to $80 \%$ at low speed intersections. A naive before-after study by Robinson et al. (2000) shows a reduction of $73 \%$ in the number of injury accidents on single-lane roundabouts. At multilane roundabouts, injury accidents are reported to decrease by $31 \%$. A study of 24 roundabouts by the Insurance Institute for Highway Safety reports a decrease of $76 \%$ in the number of injury accidents (IIHS, 2000). Although most studies suggest that roundabouts have a positive effect on road safety, there is a huge variance of results. Hence, the effectiveness of the Flemish roundabout program can not directly be inferred from previous studies.

This paper is the first to analyse the safety effects of road safety measures in Flanders, more specifically the impact of roundabouts on the number of accidents and injury severity. In 2003, a report from the Walloon government adopted a naive before-after approach in which the effect of 122 roundabouts was defined as the difference in the number of accidents and casualties before and after implementation at a particular location (M.E.T. 2003). Their analysis shows a reduction of $42 \%$ in the number of injury accidents and a reduction of $48 \%$ in the number of serious injury accidents. Since other measures or developments may also explain (part of) the improved accident results, it is imperative to compare the number and severity of accidents after implementation with the results that would have occurred if the safety measure analyzed had not been taken. In other words, since accident figures at a specific location not only measure the effect of the newly built roundabout, but also of new developments in car technology, law enforcement and health care among others, simple before-after studies will measure the impact of all these variables simultaneously. Furthermore, a significant part of road accidents happen randomly. Therefore, a comparison has to be made between locations with and without roundabouts that had similar safety characteristics beforehand. Neglecting these two aspects is likely to yield an overestimation of the safety effect associated with a particular safety measure that might be due to other causes. This distortion poses a serious policy management problem especially when, after a while, safety records start worsening again and the safety effect is questioned publicly.

The article is structured as follows. The second paragraph describes the data set. In the third paragraph, the model is specified. After checking the reliability of the comparison group, the number of accidents is estimated that would have occurred if the roundabouts had not been built taking into account the trend and the regression to the mean effect. These results are used in the fourth paragraph to calculate the safety effects of roundabouts in terms of the number and injury severity of accidents. Specific attention is paid to the impact of the length of the post-implementation period of analysis. The final paragraph concludes with some policy implications.

\footnotetext{
${ }^{1}$ In 2001, Belgium ranked $12^{\text {th }}$ of 15 countries with 14.5 fatalities per 100.000 residents compared to an average of 10.5 in the rest of the European Union (BIVV, 2001, p.50).
} 


\section{DATASET}

This study analyses the impact on road safety of 95 roundabouts that were built in Flanders between 1994 and 1999. Our database includes all registered injury accidents that occurred between 1991 and 2000 at these locations in the Flemish region. This way, calculations can be made going back at least three years before and at least one year after the construction of any particular roundabout. Furthermore, the dataset includes a comparison group of 119 road intersections without roundabouts.

Table 1 gives an overview of the number of roundabouts, crossroads (intersections of the comparison group) and accidents at both types of locations that will be examined. The roundabouts are clustered in six groups in accordance with the legal speed limit $(50,70$ and $90 \mathrm{~km} / \mathrm{h}$ ) as currently observed on the main road and the adjacent road. Each group of roundabouts has its own comparison group. As explained before, the intersections that are included in the comparison group should be similar to the locations where roundabouts were implemented. According to Hauer (1991), a comparison group should cover at least 150, preferably 300 accidents. For most locations in table 1 the number of accidents in our data set is sufficiently high.

Table 1: Number of roundabouts, intersections and accidents at both types of locations

\begin{tabular}{ccccc}
\hline $\begin{array}{c}\text { Speed limit } \\
(\mathrm{km} / \mathrm{h})\end{array}$ & $\begin{array}{c}\text { Number of } \\
\text { Main road } \mathrm{r} \\
\text { adjacent road }\end{array}$ & $\begin{array}{c}\text { Number of } \\
\text { accidents }\end{array}$ & $\begin{array}{c}\text { Number of } \\
\text { intersections }\end{array}$ & $\begin{array}{c}\text { Number of } \\
\text { accidents }\end{array}$ \\
\hline $50 \times 50$ & 33 & 682 & 16 & 299 \\
$70 \times 50$ & 23 & 547 & 39 & 578 \\
$70 \times 70$ & 15 & 289 & 37 & 681 \\
$90 \times 50$ & 8 & 104 & 11 & 530 \\
$90 \times 70$ & 9 & 200 & 10 & 512 \\
$90 \times 90$ & 7 & 123 & 6 & 256 \\
\hline Total & 95 & 1945 & 119 & 2856 \\
\hline
\end{tabular}




\section{MODEL SPECIFICATION}

The calculation of the overall reduction in injury accidents first requires an evaluation of each roundabout before a meta analysis of the clusters can be made. The first step, however, is to make sure that the intersections selected for the comparison group that hold the same exogenous characteristics (speed limits) are also similar in terms of accidents. Following Hauer (1997), an odds-ratio matching both groups is computed as follows:

\section{Define}

$\mathrm{R}_{\mathrm{t}}$ : the number of accidents in year $\mathrm{t}$ at the roundabout locations before implementation,

$\mathrm{C}_{\mathrm{t}}$ : the number of accidents in year $\mathrm{t}$ at all intersections of the comparison group.

The odds-ratio is then defined as the ratio of the change in the number of accidents at the roundabout locations before implementation and the change in the number of accidents in the comparison group. The odds-ratio for one year compared to a previous year can thus be written as:

$$
\frac{R_{t} / R_{t_{-1}}}{C_{t} / C_{t-1}}
$$

We calculated the average odds-ratios for each year before the implementation of a roundabout. For example, when a roundabout was built in 1995, the average of the odds-ratios between 1991 and 1992, 1992 and 1993 and 1993 and 1994 was calculated. Figure 1 shows the average odds-ratios for each roundabout. Hauer (1997) pointed out that the odds-ratio should be close to 1 for a comparison group to be reliable. The results in graph 1 show that our comparison groups are indeed sufficiently similar.

There are strong indications, however, that the official records significantly underreport the number of accidents ${ }^{2}$. Therefore, we calculate the adapted odds ratios to see how this underreporting affects the original odds ratios. In figure 1, the dark dots represent the original odds ratios per individual roundabout based on the official accident data. Some ratios are well above 1,5 or below 0,8 . These unsatisfactory outcomes are the result of the limited number of accidents and/or the limited number of years included in some odds ratios. If one artificially increases the number of accidents with 1 for those locations with a high or low original odds ratio or where not a single accident happened in a particular year, it is observed that the adapted odds ratio for more than two thirds of the locations lies between the acceptable range $0,8-1,2$. It is rational to assume that the fewer accidents occur at a roundabout, the more likely the odds-ratio diverges from 1 since any single accident in the following year has a stronger impact on the odds-ratio. One option could be to exclude the results for roundabouts having a very low number of accidents and thus less reliable safety effects. This would, however, lead to a bias in the overall effectiveness since information, though disturbing, would be unduly neglected. Moreover, in the meta analysis these few-accident locations will be given a lower weight (see paragraph 5). It is concluded that all locations should be included in the analysis.

\footnotetext{
${ }^{2}$ A comparison of datasets of the Antwerp police and the reported number of injury accidents in the official records shows a distortion of $66 \%$ for the year 2000 (Antwerp police, 2002, p.3).
} 
Figure 1: Average odds ratios per location

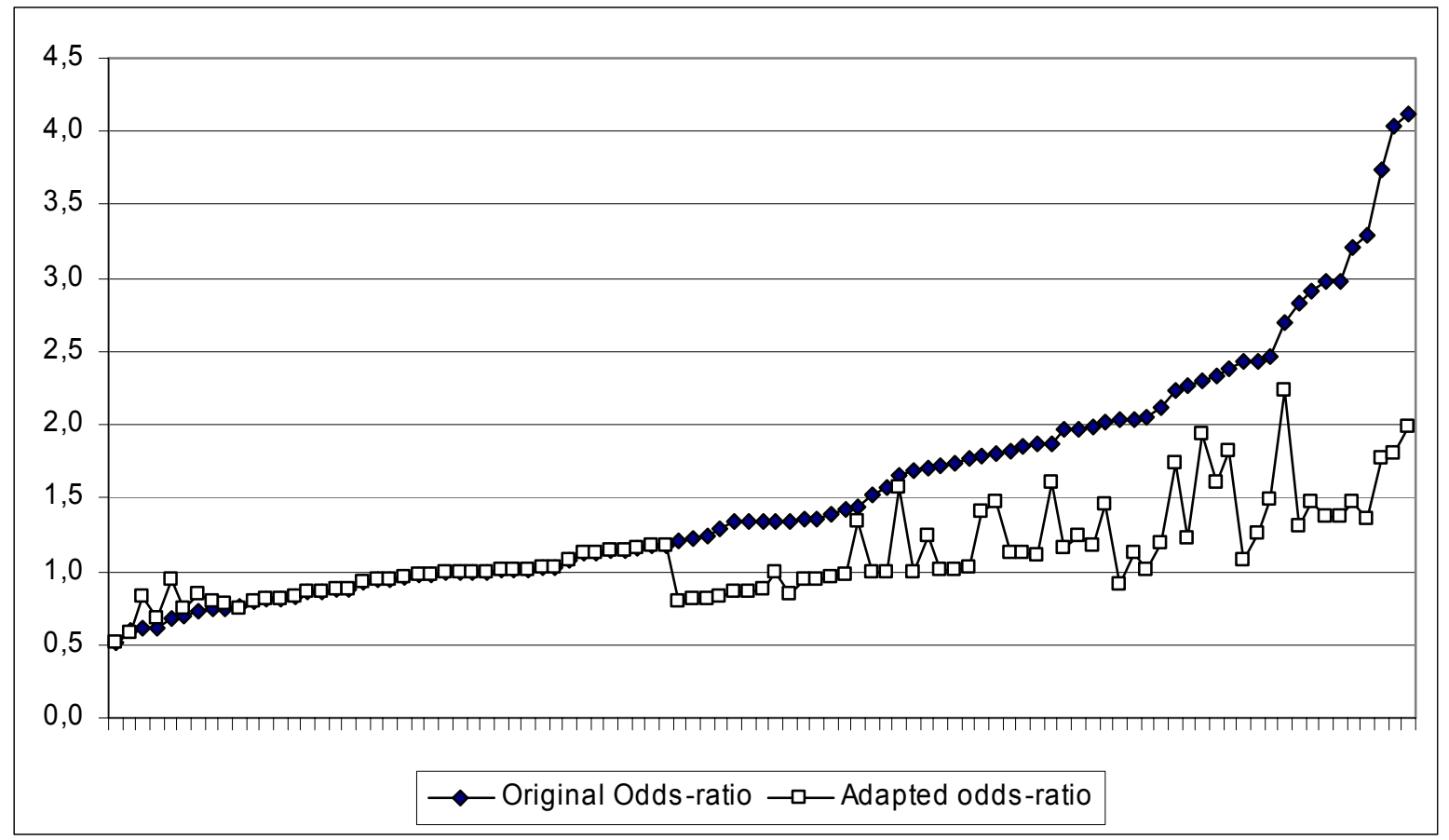

To determine effectiveness, data have to be produced about the number of accidents that would have occurred if the roundabouts had not been built. In our analysis, we do leave out the accidents in the year of construction itself. This way, we overcome the mere adaptation problems of road users (Hydén and Várhelyi, 2000). Two effects should be considered carefully: time and regression to the mean. The latter effect distinguishes between the accidents that happen by chance and those genuinely associated with the characteristics of the locations. It is highly likely that regression to the mean will occur since most roundabouts were built at sites where the level of accidents was well above average. When the observation period is often relatively short, a random increase is often mistakably interpreted as a structural problem. In Flanders, black spots are, therefore, identified using a three year observation period and funds are allocated accordingly (Geurts et al., 2004). Other European countries use a three year observation period as well to define dangerous locations (ERF, 2002).

It is evident that after the implementation of roundabouts the number of (injury) accidents decreases. This reduction, however, should not be entirely attributed to the roundabout. This is due to the fact that the number of accidents at a specific location fluctuates around the average. Possibly, the number of accidents was above or below this average at the time the roundabout was implemented. If the whole decrease in the number of accidents would be attributed to the roundabout, this would lead to a (significant) bias in the reduction of accidents due to the roundabout (Hauer, 1997).

The expected number of accidents at the location of a roundabout, as if it was not implemented, taking into account the regression to the mean effect, is computed as follows (Hauer et al. 2002):

$$
R_{r t m, T}=\mathrm{w}\left(\mu_{R+C^{\top}}\right)+(1-\mathrm{w})\left(\sum_{t=1}^{T} R_{t}\right)
$$

where 
$R_{r t m, T}=$ the expected number of accidents at the location where the roundabout was to be build, after correction for regression to the mean (rtm),

$\mu_{R+C}=$ the average number of accidents per year for the comparison group (C), including the accidents of the location where the roundabout is implemented (R). Before the implementation of the roundabout, the location is considered comparable to the comparison group and could be included,

$\mathrm{T}=$ the number of years considered,

$R_{t}=$ the number of accidents in year $\mathrm{t}$, at the location where roundabouts are implemented,

$\mathrm{w}=$ weight given to the mean number of accidents of the group,

$(1-w)=\quad$ weight given to the number of accidents of the location where the roundabout will be built

w is calculated as follows (Hauer et al. 2002):

$\mathrm{w}=\left(1+\mathrm{k} \mu_{R+C} \mathrm{~T}\right)^{-1}$

In equation (3), $w$ is the weight assigned to the comparison group while (1-w) is the weight assigned to the location where the roundabout is built. If $w$ equals 0 , the expected number of accidents is equal to the number of accidents that happened at the locations were the roundabout is to be built. Hence, there is no correction. But if $0<w<1$, then the expected number of accidents lies between the number of accidents of the location where roundabout will be built and to the mean number of accidents that are expected at this location.

$\mathrm{k}$ in equation ( 3 ) is the overdispersion parameter and is calculated as follows:

$\mathrm{k}=\frac{\sigma^{2}(R+C)-\mu_{(R+C)}}{\mu^{2}(R+C)}$

The reason why the overdispersion is necessary is a technical one (for a statistically correct, yet intuitively supported explanation, see Hauer, 2001). In short, it relaxes the assumption that accident numbers at intersections all should follow the same Poisson distribution. Its most important characteristic is that it should be positive. If not, equation (2) does not result into a regression to the mean, but into a correction away from the mean.

Equation (2) corrects the average number of accidents before the roundabout was built for the regression to the mean effect. It is now possible to correct this number once more to take into account the effect of the trend. Changes in legislation, weather conditions and improvements in car safety or changes in driver education will all have an impact that can not be attributed to the roundabouts. These overall changes in road safety can, however, be derived from the evolution in accidents at similar places, i.e. the comparison group. 
Define

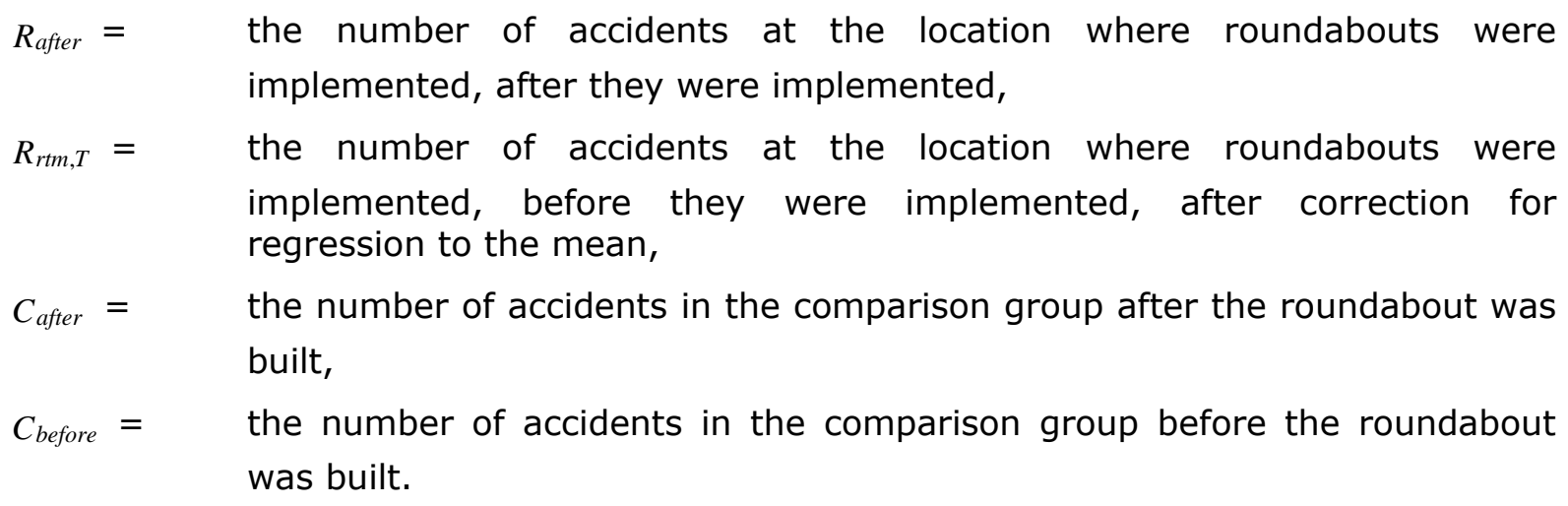

The effectiveness ratio $(\varepsilon)$ is then calculated as:

$\varepsilon=\frac{R_{\text {after }} / R_{r t m, T}}{C_{\text {after }} / C_{\text {before }}}$

with a 0.95 confidence interval:

$\exp \left[\ln \left(\frac{R_{a f t e r} / R_{r t m, T}}{C_{\text {after }} / C_{\text {before }}}\right) \pm 1.96 * \mathrm{~s}\right]$

in which $\mathrm{s}^{2}=\frac{1}{R_{\text {after }}}+\frac{1}{R_{\text {rtm }, T}}+\frac{1}{C_{\text {after }}}+\frac{1}{C_{\text {before }}}$

since the effectiveness ratio follows a lognormal distribution (Fleiss, 1981; Elvik, 1995).

Equations (2) to (7) are helpful in establishing the effectiveness of roundabout with respect to the number of accidents. But the same formulas can also be used to measure the impact on injury severity. To that end, calculations will be reiterated for each location and injury level (light, serious and fatal) counting the highest level. The formulas do not yield correct estimations when negative overdispersion occurs which is the case for fatal accidents and some (14 out of 95 locations) of the locations with severe injury accidents. This renders the use of equation (2) impossible for these locations. Since $k$ is systematically negative, calculations based on a Poisson distribution also are not valuable. Therefore, we did not calculate the effectiveness of roundabouts in reducing fatal accidents and did not include some of the locations with severe injury accidents.

The final step is to calculate the overall effectiveness ratio. To that end, the ratios of the individual roundabouts will be aggregated into one group by a meta analysis. From a policy perspective, however, valuable information would be lost when information on the effectiveness of different types of locations were no longer available. Therefore, we will calculate the overall effectiveness ratio per cluster. Such an approach allows (Flemish) policy-makers to rationally assess the road safety implications of their decisions. 
The overall effectiveness is thus the weighted average of the results over the different years. The weight assigned to the group of roundabouts is the inverted value of the variance (7):

$$
W_{i}=\frac{1}{S_{i}^{2}}
$$

This way, locations at which many accidents happened, are given a greater weight. For $\mathrm{n}$ locations, the overall number of accidents which remain (noar) after the implementation of roundabouts is calculated as follows (Fleiss, 1981 and Elvik, 1995):

noar $=\exp \left[\frac{\sum_{i=1}^{n} w_{i} \ln \left(\frac{R_{\text {after }} / R_{r t m, T}}{C_{\text {after }} / C_{\text {before }}}\right)}{\sum_{i=1}^{n} w_{i}}\right]$ 


\section{RESULTS}

\subsection{Effectiveness of roundabouts}

Table 3 presents the average percentage decrease in injury accidents at different roundabouts one year after their construction.

Table 3: Reduction of accidents at roundabouts one year after construction until 2000

\begin{tabular}{cccc}
\hline $\begin{array}{c}\text { Speed limit }(\mathrm{km} / \mathrm{h})- \\
\text { major road } \mathrm{x} \text { adjacent road }\end{array}$ & Average reduction of accidents & \multicolumn{2}{c}{ Confidence Interval (.95) } \\
\hline $50 \times 50$ & $39 \% *$ & $24 \%$ & $50 \%$ \\
$70 \times 50$ & $15 \%$ & $-5 \%$ & $30 \%$ \\
$70 \times 70$ & $42 \% *$ & $17 \%$ & $59 \%$ \\
$90 \times 50$ & $55 \% *$ & $18 \%$ & $76 \%$ \\
$90 \times 70$ & $59 \% *$ & $44 \%$ & $71 \%$ \\
$90 \times 90$ & $18 \%$ & $-24 \%$ & $46 \%$ \\
\hline All & $34 \% *$ & $28 \%$ & $43 \%$ \\
\hline
\end{tabular}

*: statistically significant at $5 \%$ level

From table 3, the following observations can be inferred:

- Overall, roundabouts lead to a reduction of $34 \%$ in the number of injury accidents. The construction of roundabouts leads at every type of junction to a substantial reduction in the number of accidents, but their impact does vary significantly among locations. The reductions observed are all but two statistically significant $(p<0.05)$ since the confidence intervals for all intersection types are positive (a negative value would imply an increase in the number of accidents).

- The strongest average reduction in road accidents (59\%) can be observed at roundabouts built on intersections with a $90 \times 70 \mathrm{~km} / \mathrm{h}$ speed limit. The confidence interval confirms that the largest reduction of accidents is to be expected here. The second best result ( a reduction of $55 \%$ ) is observed at roundabouts where the speed limit is $90 \times 50 \mathrm{~km} / \mathrm{h}$.

- Roundabouts located at intersections where both roads have the same speed limit $(50 \times 50 \mathrm{~km} / \mathrm{h}$ and $70 \times 70 \mathrm{~km} / \mathrm{h}$ ) lead to a lower reduction in the number of injury accidents, $39 \%$ and $42 \%$ respectively.

- The smallest reductions are observed on roundabouts at $70 \times 50 \mathrm{~km} / \mathrm{h}$ and $90 \times 90$ $\mathrm{km} / \mathrm{h}$ intersections, respectively $15 \%$ and $18 \%$. Moreover, the reduction in the number of accidents at these locations is not statistically significant.

While table 3 provides valuable information on the reduction of the number of accidents, the improvements in safety due to roundabouts should also be judged in terms of injury severity. Table 4 shows the reduction in the number of all injury, light injury and serious injury accidents. To avoid interference of the number of casualties involved in one accident with the effectiveness ratio, the accidents were labelled in accordance with the most serious injury. This way, the calculation of the reduction in the number of accidents per injury type can be repeated in the same way as we did in table 3 for all injury accidents. 
Table 4: Reduction in the number of accidents due to roundabouts for all injury accidents from the first year after construction until 2000

\begin{tabular}{cccc}
$\begin{array}{c}\text { Speed limit } \begin{array}{c}\mathrm{km} / \mathrm{h})- \\
\text { major road } \mathrm{x} \text { adjacent } \\
\text { road }\end{array} \\
50 \times 50\end{array}$ & $\begin{array}{c}\text { Reduction in the } \\
\text { number of accidents }\end{array}$ \\
\cline { 2 - 4 } $70 \times 50$ & $\begin{array}{c}\text { Reduction in the number of } \\
\text { light injury accidents }\end{array}$ & $\begin{array}{c}\text { Reduction in the number of } \\
\text { serious injury accidents }\end{array}$ \\
$70 \times 70$ & $42 \%(24 \%, 50 \%)^{*}$ & $37 \%(19 \%, 51 \%)^{*}$ & $28 \%(-29 \%, 60 \%)$ \\
$90 \times 50$ & $55 \%(18 \%, 76 \%)^{*}$ & $45 \%(-7 \%, 72 \%)$ & $36 \%(-4 \%, 60 \%)$ \\
$90 \times 70$ & $59 \%(44 \%, 71 \%)^{*}$ & $40 \%(8 \%, 61 \%)^{*}$ & $50 \%(-13 \%, 78 \%)$ \\
$90 \times 90$ & $18 \%(-24 \%, 46 \%)$ & $7 \%(-48 \%, 42 \%)$ & $72 \%(42 \%, 86 \%)^{*}$ \\
\hline All locations & $34 \%(43 \%, 28 \%)^{*}$ & $30 \%(19 \%, 39 \%)^{*}$ & $27 \%(-77 \%, 70 \%)$ \\
\hline
\end{tabular}

a $95 \%$ confidence interval between parentheses. $*$ : statistically significant at $5 \%$ level.

A negative number means an increase in the number of accidents.

From table 4 it can be concluded that:

- The construction of roundabouts located at $90 \times 70 \mathrm{~km} / \mathrm{h}$ and $90 \times 50 \mathrm{~km} / \mathrm{h}$ intersections leads to the most important reductions in the total number of injury accidents. This is also true for serious injury accidents. The largest effect on light injury accidents is found on $90 \times 50 \mathrm{~km} / \mathrm{h}$ intersections.

- Roundabouts at $70 \times 70 \mathrm{~km} / \mathrm{h}$ intersections lead to a considerable reduction in the number of serious injury accidents $(50 \%)$, which is considerably higher compared to all injury accidents and light injury accidents at roundabouts located at $70 \times 70 \mathrm{~km} / \mathrm{h}$ intersections. This implies that roundabouts located at roads with these speed limits are a good investment despite the lower overall reduction in the number of injury accidents.

- Roundabouts located at $90 \times 90 \mathrm{~km} / \mathrm{h}$ roads produce the lowest reduction in the number of accidents. This is also true for light and serious injury accidents. Moreover, none of the reductions at this type of location are statistically significant.

- All roundabouts together show a statistically significant reduction of accidents for each injury level. In case of severe injury accidents it should be noted that the reductions obtained are not statistically significant for each individual cluster of roundabouts (except at $90 \times 70 \mathrm{~km} / \mathrm{h}$ locations). Our best estimate, however, shows an important reduction in the number of accidents for each cluster of roundabouts. Only roundabouts located at $50 \times 50 \mathrm{~km} / \mathrm{h}$ roads seem to result in a lower reduction in the number of serious injury accidents compared to the reduction in the number of light injury accidents.

\subsection{Time-series analysis of effectiveness}

When an innovative road safety measure is implemented, policy-makers wish to know its impact as quickly and accurately as possible before making further implementations elsewhere. In the literature, a post-implementation observation period of typically three years is advocated though a longer time span is not undesired (Harwood et al. 2003; Zaloshnja et al., 2003; El-Sadig et al., 2004; Simpson, 2003).

Table 5 shows that the error in the effectiveness measurement due to a limited (one year) post-implementation time period can be significant. For example, six years of 
accident data after the construction of roundabouts at $70 \times 70 \mathrm{~km} / \mathrm{h}$ roads reveal a reduction of the number of accidents five times larger compared to the one year data set ( $70 \%$ vs. $12 \%)$. In general, however, the effectiveness is more likely to increase when a 3 -year time period is used instead of a 1-year period. When the after period is extended to 6 years, it is not uniformly clear whether biases are upward or downward, though biases are fairly limited on locations with lower speed limits.

Table 5: Average cumulative reduction of accidents at roundabouts using different postconstruction periods

\begin{tabular}{|c|c|c|c|c|c|c|c|c|c|}
\hline \multirow[t]{2}{*}{$\begin{array}{c}\text { Speed limit } \\
\text { at } \\
\text { roundabout }\end{array}$} & \multicolumn{6}{|c|}{$\begin{array}{c}\text { Number of years considered after construction of } \\
\text { roundabout }\end{array}$} & \multicolumn{3}{|c|}{ Absolute difference* } \\
\hline & 1 year & 2 years & 3 years & 4 years & 5 years & 6 years & $\begin{array}{l}1 \text { vs. } 3 \\
\text { year }\end{array}$ & $\begin{array}{l}1 \text { vs. } 6 \\
\text { year }\end{array}$ & $\begin{array}{l}6 \text { vs. } 3 \\
\text { year }\end{array}$ \\
\hline \multicolumn{10}{|c|}{ Reduction in injury accidents } \\
\hline $50 \times 50$ & $29 \%$ & $40 \%$ & $48 \%$ & $44 \%$ & $43 \%$ & $44 \%$ & $-19 \%$ & $-15 \%$ & $-4 \%$ \\
\hline $70 \times 50$ & $3 \%$ & $7 \%$ & $10 \%$ & $7 \%$ & $1 \%$ & $9 \%$ & $-7 \%$ & $-6 \%$ & $-1 \%$ \\
\hline $70 \times 70$ & $12 \%$ & $27 \%$ & $28 \%$ & $50 \%$ & $53 \%$ & $70 \%$ & $-16 \%$ & $-58 \%$ & $42 \%$ \\
\hline $90 \times 50$ & $26 \%$ & $42 \%$ & $40 \%$ & $73 \%$ & n.a. & n.a. & $-14 \%$ & - & - \\
\hline $90 \times 70$ & $45 \%$ & $58 \%$ & $60 \%$ & $61 \%$ & $57 \%$ & $16 \%$ & $-15 \%$ & $29 \%$ & $-44 \%$ \\
\hline $90 \times 90$ & $-21 \%$ & $-7 \%$ & $7 \%$ & $27 \%$ & $22 \%$ & $32 \%$ & $-28 \%$ & $-52 \%$ & $24 \%$ \\
\hline All locations & $18 \%$ & $30 \%$ & $35 \%$ & $39 \%$ & $37 \%$ & $34 \%$ & $-17 \%$ & $-16 \%$ & $1 \%$ \\
\hline \multicolumn{10}{|c|}{ Reductions in accidents with only light injuries } \\
\hline $50 \times 50$ & $30 \%$ & $37 \%$ & $50 \%$ & $45 \%$ & $43 \%$ & $43 \%$ & $-20 \%$ & $-13 \%$ & $-7 \%$ \\
\hline $70 \times 50$ & $-12 \%$ & $-3 \%$ & $1 \%$ & $-1 \%$ & $-15 \%$ & $-8 \%$ & $-13 \%$ & $-4 \%$ & $-9 \%$ \\
\hline $70 \times 70$ & $-6 \%$ & $22 \%$ & $21 \%$ & $46 \%$ & $52 \%$ & $65 \%$ & $-27 \%$ & $-72 \%$ & $44 \%$ \\
\hline $90 \times 50$ & $6 \%$ & $23 \%$ & $63 \%$ & $75 \%$ & n.a. & n.a. & $-57 \%$ & - & - \\
\hline $90 \times 70$ & $6 \%$ & $40 \%$ & $38 \%$ & $42 \%$ & $43 \%$ & $5 \%$ & $-32 \%$ & $2 \%$ & $-33 \%$ \\
\hline $90 \times 90$ & $25 \%$ & $-19 \%$ & $-5 \%$ & $17 \%$ & $23 \%$ & $18 \%$ & $30 \%$ & $7 \%$ & $23 \%$ \\
\hline All locations & $9 \%$ & $19 \%$ & $27 \%$ & $30 \%$ & $29 \%$ & $28 \%$ & $-18 \%$ & $-19 \%$ & $1 \%$ \\
\hline \multicolumn{10}{|c|}{ Reduction in accidents with at least one serious injury } \\
\hline $50 \times 50$ & $-12 \%$ & $30 \%$ & $38 \%$ & $38 \%$ & $38 \%$ & $33 \%$ & $-50 \%$ & $-46 \%$ & $-5 \%$ \\
\hline $70 \times 50$ & $-11 \%$ & $27 \%$ & $48 \%$ & $36 \%$ & $33 \%$ & $42 \%$ & $-59 \%$ & $-53 \%$ & $-6 \%$ \\
\hline $70 \times 70$ & $-8 \%$ & $49 \%$ & $8 \%$ & $77 \%$ & $78 \%$ & $65 \%$ & $-16 \%$ & $-73 \%$ & $56 \%$ \\
\hline $90 \times 50$ & $-21 \%$ & $20 \%$ & $50 \%$ & $67 \%$ & n.a. & n.a. & $-71 \%$ & - & - \\
\hline $90 \times 70$ & $33 \%$ & $67 \%$ & $72 \%$ & $75 \%$ & $78 \%$ & $56 \%$ & $-39 \%$ & $-23 \%$ & $-16 \%$ \\
\hline $90 \times 90$ & $24 \%$ & $28 \%$ & $20 \%$ & $40 \%$ & $39 \%$ & $58 \%$ & $+4 \%$ & $-34 \%$ & $38 \%$ \\
\hline All locations & $-3 \%$ & $38 \%$ & $48 \%$ & $51 \%$ & $56 \%$ & $48 \%$ & $-51 \%$ & $-51 \%$ & $0 \%$ \\
\hline
\end{tabular}

* a negative number stands for an underestimation. 
Looking at the right columns in table 5 it is seen that a one year period after the implementation underestimates the longer term safety effects. In order to calculate these long term safety effects, one option would be to wait until more data becomes available since this would imply more reliable outcomes. This is, however, difficult since investments in road safety are, obviously, preferred rather sooner than later. Our calculations indicate that, all locations taken together, a period of 3 years gives a good insight to the longer term safety effects. For all accidents together, or accidents with only light injuries or at least one serious injury separately, the safety effects observed after 6 years (the maximum number of years in our dataset) are exactly the same compared to a period of 3 years. This is important since it urges decision makers to consider a relatively short period of time (longer than 1 year, preferably 3 years) before longer term safety effects can be estimated. Obviously this does not mean that an analysis after 1 year is not useful: if investments are socially beneficial after one year, our results show that the implementation of similar investments would even be more beneficial.

The reduction in the number of injury accidents is also presented for the individual clusters of roundabouts. The same type of underestimation of the safety effects is observed if only one year is included in the calculations. However, while the deviation between a 3-year or 6-year period is negligible when all roundabout locations are considered together, it should be kept in mind that for the individual clusters of roundabouts there is still a significant difference in the calculated safety effects. This difference is relatively small for the roundabouts located at roads with lower speed limits, but it is considerable for roads with higher speed limits.

These different safety effects, depending on calculations using different periods after roundabouts are built, are important since many investments in road safety, especially in road infrastructure, have a lifespan of many years up to decades. Suppose for example that five accidents happen every year each involving one seriously injured person at a $90 \times 70 \mathrm{~km} / \mathrm{h}$ intersection. One year of accident data after the construction of the roundabout would reveal savings of $1,7(0.33 \times 5)$ serious casualties each year. Using 3 years of data, $3,6(0.72 \times 5)$ serious casualties would be saved each year. The reduction in accidents deduced from 6 years of post-construction accident data would predict a decrease of 2,8 $(0.56 \times 5)$ seriously injured victims. Though the absolute numbers may seem small, they are likely to have a decisive impact on the outcome of cost-benefit analyses giving insight into the social desirability of this safety measure.

\subsection{Learning effects of road users}

Table 6 presents the reduction in the number of accidents per individual year after the implementation of the roundabouts compared to the before period corrected for trend and regression to the mean. It could be possible that road users become experienced in 'using' the safety measure. This would lead to an increasing reduction in the number of accidents over the subsequent years. The opposite could happen as well: as road users are becoming more experienced in 'using' the safety measure, they could show a more dangerous behavior resulting in a decreasing reduction in the number of accidents. This implies a moral hazard effect amongst road users which reduces the effectiveness of the roundabout. Looking at table 6 none of the two mentioned scenarios seems to have the upper hand ${ }^{3}$. So, from this dataset it is not clear whether one of the two effects is present.

\footnotetext{
${ }^{3}$ Some percentages in table 6 may look contradictory to the cumulative results in table 5 . This is due to the weight (see equation 8) which is assigned to the individual locations in a cluster when the effectiveness is calculated. This weight depends on the number of accidents which happened during the before and after period, on the location where the roundabout is built and the comparison group. This way it is possible for a roundabout to have different weights in different effectiveness calculations. An example of the calculation is given in appendix 1.
} 
Table 6: Reduction in the number of accidents, per year after the implementation of roundabouts

\begin{tabular}{|c|c|c|c|c|c|c|}
\hline $\begin{array}{c}\text { Speed limit (Main road } \\
\text { × adjacent road }\end{array}$ & 1st year & 2nd year & 3rd year & 4th year & 5th year & 6 th year \\
\hline $50 \times 50$ & $29 \%$ & $22 \%$ & $33 \%$ & $-2 \%$ & $7 \%$ & $15 \%$ \\
\hline $70 \times 50$ & $3 \%$ & $16 \%$ & $7 \%$ & $-3 \%$ & $35 \%$ & $35 \%$ \\
\hline $70 \times 70$ & $12 \%$ & $28 \%$ & $-13 \%$ & $43 \%$ & $36 \%$ & $20 \%$ \\
\hline $90 \times 50$ & $26 \%$ & $-9 \%$ & $53 \%$ & $58 \%$ & - & - \\
\hline $90 \times 70$ & $45 \%$ & $57 \%$ & $29 \%$ & $60 \%$ & $32 \%$ & $-1 \%$ \\
\hline $90 \times 90$ & $-21 \%$ & $-92 \%$ & $8 \%$ & $44 \%$ & $67 \%$ & $-45 \%$ \\
\hline All locations & $18 \% \rightarrow 17 \%$ & $-18 \%$ & $18 \%$ & $11 \%$ & $12 \%$ \\
\hline
\end{tabular}




\section{DISCUSSION}

This study analyzes the road safety effects of roundabouts built in Flanders between 1994 and 1999. To that end, the reductions were calculated with regard to the number of accidents as well as injury severity taking into account the trend and regression to the mean effect and making use of a large data set that holds information of accident data of at least three years before the construction of the roundabouts. Six types of roundabouts were distinguished on the basis of speed limit regime on the main and adjacent roads.

The overall conclusion is that Flemish roundabouts are effective tools in improving road safety. The robust overall reduction in injury accidents ranges from 15 to 59\%, with an average of $34 \%$. But road safety effects do vary significantly among different types of intersections. Roundabouts seem most effective when implemented at faster roads. They reduce the number of accidents at $90 \times 70 \mathrm{~km} / \mathrm{h}$ and $90 \times 50 \mathrm{~km} / \mathrm{h}$ roads with $59 \%$ and $55 \%$ respectively. Smaller roads $(50 \times 50 \mathrm{~km} / \mathrm{h}$ or $70 \times 50 \mathrm{~km} / \mathrm{h}$ ) face an effectiveness of $42 \%$ and $21 \%$ respectively. All results but one are statistically significant. From a policy perspective, it is promising to learn that roundabouts give rise to significant reductions in the number of accidents. But it should be kept in mind that the effects differ with the type of intersection. Furthermore, it was found that the reduction per injury severity type also varies.

Such results are indispensable in designing an optimal road safety policy. Once policymakers have assigned (cost-based) weights to each injury type, rational choices can be made between alternative road safety investments. The significant reduction of accidents due to the implementation of roundabouts should not be interpreted as if roundabouts are the sole effective measure. An optimal allocation of a road safety budget requires additional cost-benefit analyses of alternative policy instruments. Nevertheless, in spite of this warning for an overenthusiastic implementation, this study clearly shows that roundabouts are effective tools to reduce accidents on Flemish roads.

This paper also lays bare the decisive influence of the length of the post-implementation time period on the effectiveness ratios. Apparently, the effectiveness ratio changes with the time span considered. Understandably, policy-makers want to find out the impact of their decisions sooner rather than later in order to withdraw or start implementing them on a larger scale. Yet, our analysis shows that patience is virtuous. More data over a longer time period after the construction of a roundabout will not only lead to just more accurate, but sometimes even opposite results. This, in turn, may greatly influence the efficacy and efficiency of future policies and investments. A meaningful cost-benefit analysis which uses these reductions to provide insight into the efficiency of the roundabouts requires that costs and benefits are measured over the entire lifespan of a project. In other words, a sufficiently long time period should be considered. Longer term effectiveness may differ significantly, positively or negatively, from short term measurements. Our calculations show that the effectiveness based on a one year postimplementation period compared to a common three years leads to an underestimation of accident reduction. Similar results are found for the reduction of accidents per injury type. It is sometimes assumed that the effect of road safety measures increase (learning effect) or decrease (moral hazard effect). From our analysis none of the two seem to apply to roundabouts in Flanders.

The standard method to calculate the reduction in accidents is based on a classic negative binomial distribution adapted for over-dispersion. We noted that overdispersion was negative for fatal injury accidents at all locations and for some of the locations where severe injury accidents were examined. This raises the question whether fatal accidents can be treated in the same manner as all injury or light injury accidents and whether overdispersion of fatal accidents occurs for other safety measures as well. More research is needed in this area. 


\section{ACKNOWLEDGEMENTS}

The authors wish to acknowledge the financial support and practical assistance in data collection by the Flemish Administration for Road Traffic for this research project. 


\section{REFERENCES}

Antwerp police (2002), Verkeersveiligheidsplan. Basisplan. Antwerp: Antwerp police.

BIVV (2001), Verkeersveiligheidsstatistieken 2001, Brussel: Belgisch Instituut voor de Verkeersveiligheid.

El-Sadig M. et al. (2004), "Evaluation of effectiveness of safety seatbelt legislation in the United Arab Emirates", Accident Analysis and Prevention, 36, 399-404.

Elvik, R. (1995), "The Safety Value of Guardrails and Crash Cushions: a Meta-analysis of Evidence from Evaluation Studies", Accident Analysis \& Prevention, 27 (4), 523-549.

ERF (2002), Good-practice guidelines to infrastructural road safety. Brussels: European Union Road Federation.

Fleiss, J. (1981), Statistical methods for rates and proportions. New York: John, Wileys and Sons.

Geurts K. (2004), "Grote en kleine middelen om de verkeersveiligheid te verhogen: Hoe rangschikken en selecteren we gevaarlijke punten?" in: Jaarboek Verkeersveiligheid 2004, Vlaams Congres Verkeersveiligheid, 2004, Brussel, p.44-46.

Harwood, D.W. et al. (2003), "Safety Effectiveness of Intersection Left- and Right-Turn Lanes", Transportation Research Record N 1840, 131-139.

Hauer, E. (1991), "Should Stop Yield? Matters of Method in Safety Research", ITE J ournal, 61 (9), 25-32.

Hauer, E. (1997), Observational Before-after Studies in Road Safety. Estimating the Effect of Highway and Traffic Engineering Measures on Road Safety. Oxford: Pergamon, Elsevier Science.

Hydén, C. and Várhelyi, A. (2000), "The Effects on Safety, Time Consumption and Environment of Large Scale Use of Roundabouts in an Urban Area: A Case Study", Accident Analysis \& Prevention, 32 (1), 11-23.

Insurance Institute for Highway Safety, (2000), "Roundabouts are becoming more familiar on U.S. roads, not just for safety reasons", Status Report 35 (5), 1-3.

M.E.T. (2003), Evaluation et accidentologie des giratoires et feux tricolores, Ministère wallon de l'Equipement et des Transports, Direction générale des Autoroutes et des Routes.

Ogden, K.W. (1996), Safer Roads: A Guide to Road Safety Engineering. Monash University: Institute of Transport Studies.

Robinson, B.W. et al, (2000), Roundabouts: an informational guide, Washington: U.S. Department of Transportation, Federal Highway Administration, Report FWHA-RD-00067.

Simpson, H.M. (2003), "The evolution and effectiveness of graduated licensing", Journal of Safety Research, 34, 25-34.

Zaloshnja et al. (2003), "Reducing injuries among Native Americans: five cost-outcome analyses", Accident Analysis and Prevention, 35, 631-639. 


\section{APPENDIX}

To illustrate the reason for the non intuitive results when safety effects are considered for different time periods, consider Table A.1. In this table we have two locations where a roundabout is built, $R_{1}$ and $R_{2}$. The comparison group consists of two other locations, $C_{1}$ and $\mathrm{C}_{2}$. Assume we have two years of accident data available before the roundabout was built (Before 1 and Before 2 ) and two years of accident after the roundabouts were built (After 1 and After 2).

Table A.1: Number of accidents at two locations before and after a roundabout was built and for its comparison group

\begin{tabular}{ccccc|ccc}
\hline & Before 1 & Before 2 & After Year 1 & After Year 2 & $\begin{array}{l}\text { Eff. } \\
\text { year }\end{array}$ & $\begin{array}{l}\text { 1st Eff. 2nd } \\
\text { year }\end{array}$ & Eff 1st + 2nd year \\
\hline $\mathrm{R}_{1}$ & 100 & 100 & 10 & 10 & $10 \%$ & $10 \%$ & $10 \%$ \\
\hline $\mathrm{R}_{2}$ & 100 & 100 & 100 & 100 & $100 \%$ & $100 \%$ & $100 \%$ \\
\hline $\mathrm{C}_{1}$ & 100 & 100 & 100 & 100 & & & \\
\hline $\mathrm{C}_{2}$ & 100 & 100 & 100 & 100 & & & \\
\hline
\end{tabular}

The overall effectiveness for roundabouts at $R_{1}$ and $R_{2}$ is a weighted average of the two individual locations. We expect the average to be somewhere between 10 and $100 \%$. The weight $\left(w_{i}\right)$ for an individual location is given by equation 7 and 8 :

$$
w i=\frac{1}{\frac{1}{R i, \text { after }}+\frac{1}{R i, \text { before }}+\frac{1}{C i, \text { after }}+\frac{1}{C i, \text { before }}}
$$

The relative weight for an individual location in the overall effectiveness is $p_{i}$ :

$$
p i=\frac{w_{i}}{\sum_{i} w_{i}}
$$

In table A. 2 we present the effectiveness for the two locations. First we consider the situation in which only one year is taken into account (it does not matter whether this is the first or second year only, the effectiveness is the same). It is seen that the overall effectiveness amounts to $63 \%$, the number of accidents decreased with $37 \%$. Locations 1 and 2 had a weight in the overall effectiveness of $20 \%$ and $80 \%$ respectively.

Now consider the same data, with the same effectiveness for each individual location, but now the two years of after period are taken into account. As a consequence of the increase in the absolute number of accidents, the weights for each individual location increases. The relative weight of location 1 increases, however, and obviously the relative weight of location 2 decreases. As can be seen the overall effectiveness when the two years are considered independently changes from $63 \%$ in the first calculation to $58 \%$ when 2 years of accident data in the after period are considered together. This is because $R_{1}$ receives a higher weight in the overall effectiveness (24\% instead of $20 \%$ ) when the years in the after period are taken into account. 
Table A.2: Effectiviness 1st year only and 1st and 2nd year taken together

\begin{tabular}{l|c|c|c|c|c|c|c|c}
\hline 1st year only & $\mathrm{R}_{\mathrm{i}}$, before & $\mathrm{R}_{\mathrm{i}}$, after & $\mathrm{C}_{\mathrm{i}}$, before & $\mathrm{C}_{\mathrm{i}}$, after & $\mathrm{Eff}$ & si2 & wi & $\mathrm{pi}$ \\
\hline $\mathrm{R}_{1}$ & 200 & 10 & 200 & 100 & $10 \%$ & 0,12 & 8,33 & $20 \%$ \\
$\mathrm{R}_{2}$ & 200 & 100 & 200 & 100 & $\begin{array}{c}100 \\
\%\end{array}$ & 0,03 & 33,33 & $80 \%$ \\
\hline Overall effectiveness & $63 \%$ & & & & & & & \\
\hline 1 st and 2nd year together & $\mathrm{Ri}$, before & $\mathrm{Ri}$, after & $\mathrm{Ci}$, before & $\mathrm{Ci}$, after & $\mathrm{Eff}$ & $\mathrm{si2}$ & $\mathrm{wi}$ & $\mathrm{pi}$ \\
\hline $\mathrm{R}_{1}$ & 200 & 20 & 200 & 200 & $10 \%$ & 0,07 & 15,38 & $24 \%$ \\
$\mathrm{R}_{2}$ & 200 & 200 & 200 & 200 & $\begin{array}{c}100 \\
\%\end{array}$ & 0,02 & 50,00 & $76 \%$ \\
\hline Overall effectiveness & $58 \%$ & & & & & & & \\
\hline
\end{tabular}

